\title{
An Analysis of Teacher Views on the Prestige of Teaching Profession in Turkey
}

\author{
Şule Firat Durdukoca \\ Correspondence: Şule Firat Durdukoca, Kafkas University, Faculty of Education, Turkey.
}

Received: December 3, 2018

Accepted: December 18, 2018 Online Published: December 24, 2018

doi:10.11114/jets.v7i1.3825

URL: https://doi.org/10.11114/jets.v7i1.3825

\begin{abstract}
This study aimed at exploring how teachers consider the prestige of their profession in Turkish society. It was conducted using the phenomenology design, which is a qualitative research method. The study group consisted of 674 teachers who participated in the study on a voluntary basis. Participants were selected using the maximum variation sampling method. Research data was collected through interview method and a semi-structured interview form was used as data collection tool. In line with the aim of the study, content analysis was performed by the researcher and an expert, individually, to analyze the data. At the end of the study, it was found that $82 \%$ of the participants stated that teaching is not a prestigious profession in Turkey. The teachers also added that the prestige of the teaching profession in Turkey varies across regions with different socio-economic characteristics, across institutions (public-private) and according to the level of teaching, and recommended that steps should be taken to increase social awareness about the significance of the profession.
\end{abstract}

Keywords: education, teaching profession, professional prestige

\section{Introduction}

The importance attached to education system in a society exposes this society's effort to exist, reflects its development level and demonstrates the qualified human resource it has. Thus, education system, teaching philosophy, required qualifications for individuals to be trained, and teachers who will train these individuals as well as the value attributed to them in society have a special meaning.

The value attributed to teachers by Turkish society, i.e. the perceived value of the teaching profession has undergone a historical change. Since the Seljuk and Ottoman periods until recently, teaching was one of the well-regarded and respected professions in Turkish society. For instance, Ottomans determined certain qualifications for teachers who would be teaching in local schools and prepared a separate curriculum for those who would serve in these schools during the reign of Mehmet the Conqueror in the $15^{\text {th }}$ century (Demirtaş, 2007). Changes and developments in the field of teacher training continued throughout the $19^{\text {th }}$ century, and the first teacher training school named "Darülmuallimin" was opened in 1848 to train male teachers for rüsstiye (today's junior high school). The regulations prepared by Ahmet Cevat Efendi, the school's principle, and state that the main element that enlivens and sustains schools is teacher, stress the concept of "teacher prestige" with a modern approach for the first time and also explain how this prestige can be ensured and preserved (Akyüz, 2006). Village Institutes that was opened after the establishment of the Republic aimed to train teachers who would be teaching in rural areas. Thanks to their high quality education based on life-wide practices, teachers who graduated from village institutes attained a status allowing them to have a voice in almost every issue in the villages they were appointed, which made a significant contribution to increase the respect accorded to teaching profession and teachers (Karamustafaoğlu \& Özmen, 2004). After dissolved in 1953, Village Institutes were reorganized as 6 year "Primary Teacher Schools", and these schools continued their existence in the teacher training system until the 1970s (The Council of Higher Education [CoHE], 1998).

The prestige of teaching as a profession was sustained until the 1970s, after which it started to decline gradually with rapid social and political change as well as industrialisation. With the emergence of new career fields in the 1980s in addition to gradual decrease in teachers' income level, the teaching profession lost its previous reputation with each passing day (Aycan, 2015). When the task of teacher training was given to universities in 1982, education faculties served to train qualified teachers needed in the Turkish education system. However, several problems arose in teacher training, particularly in the late 1990s since an innovation policy in line with the needs of Turkish education system was not pursued. In this period, departments were opened in accordance with the academic staff's orientation in the faculties 
of education, and so, there became a teacher shortage in certain areas while some other areas generated teacher surplus in the country. Thus, particularly the departments with teacher shortage was opened to people specialized in other career fields, and the teaching profession became a beacon of hope for the college graduates who were unable to find a job, and no doubt that the status and prestige of the teaching profession declined in society (Çelikten, Şanal \& Yeni, 2005). Moreover, in recent years, constant and radical changes in the education system, random interventions in education and training process, and various challenges in projecting the developments in the organization of learning environment and information and technology to learning environment put teachers under the spotlight and they were simply portrayed as the source of problems in the Turkish education system, with the result that the social status of the teaching profession gradually advanced in a negative course (TEDMEM, 2014). Indeed, in a study by Özpolat (2002), a great majority of participants stated that their social status decreased gradually over the years. Reviewing literature on the teaching profession and the social status and roles of teachers, Başkan (2001) indicated that teaching is regarded as a profession in every society while the social status of the teaching profession has undergone fluctuations over time and declined considerably particularly in recent years in Turkey.

There are research findings demonstrating that the prestige of the teaching profession has decreased in many European countries as in Turkey. For example, the research report "Study on Policy Measures to improve the Attractiveness of the Teaching Profession in Europe" (Carlo et al, 2013) stated that the teaching profession has lost much of its capacity to attract the best candidates in most European countries because the prestige of the profession has declined, working conditions have deteriorated and teachers get relatively low salaries compared with other intellectual professions. In his study aimed at analyzing the knowledge of education unions about teachers and the teaching profession globally, Symeonidis (2015) reported that there is a general decline in the social status of the teaching profession in the European countries and this decline is more evident in the crisis-affected European countries. In a study on the social prestige of the teaching profession in Spain, Aparicio \& Arévalo (2014) reported that only 7\% of the participants recommended preschool, primary or secondary education teaching as a career to their children while 50\% considered that preschool teachers do not have social prestige, and $47 \%$ thought the same about primary teachers. Furthermore, it is seen that the profession has maintained or improved social prestige in various countries in Europe and across the world. Larsen (2006) maintained that the teaching profession had high public prestige, and teachers were accorded high esteem by students, parents and principals in the US state of Connecticut. The researcher reported that there was an abundance of teachers in the state, which resulted in competition for teaching levels, there were strict acceptance standards for teacher training, but high quality training was provided, and there was a comprehensive support system for new graduate teachers while well-prepared professional training opportunities were offered for all teachers. Also, Sahlberg (2011) stated that in Finland, teacher education programs admitted only the most capable candidates and in opinion surveys, teaching is consistently rated as a highly prestigious profession.

Evidence provided by the OECD PISA (The Programme for International Student Assessment) and TALIS (Teaching and Learning International Survey) demonstrates that societies which attach value to the teaching profession have the most successful education systems (Schleicher, 2018). Negative perceptions of teachers and teacher candidates as the teachers of future toward the decline in the prestige of their profession in society can affect their career, resulting in obstacles at various levels in achieving the desired quality in the education system. Cognizant of the gravity of the situation, the Ministry of National Education (MoNE, 2017) started to take significant steps, and set three main goals in its Teacher Strategy Paper concerning teacher training, development and employment processes. One of these goals is to improve the perception toward teaching profession and increase its professional prestige in Turkey. The paper underscored that teachers should strive for professional development to increase their professional prestige and recommended to implement a periodical performance evaluation system to identify teachers' need for development. The aim of performance evaluation system is to expose teachers' needs for continuing professional development in an objective way, encourage teachers for continuing professional development and hence, increase the professional prestige by taking into account self-assessment and persons who can provide the most accurate and objective feedback to the teacher like school principal, colleagues, students and parents. Some countries have already adopted the approach to evaluate teacher performance through the use of various data sources. In China, a system allowing students to assess their teachers is widely used, but also gives rise to discussions. Liu \& Teddlie (2005; as cited in Brog, 2018) summarized several studies on the topic and cited a study conducted by Wang \& Sui (2005) that indicated the school principals and teachers were in favour of using student assessments in 10 schools. In the same study, the researchers mentioned various concerns of teachers like trying to satisfy students to get positive scores. In addition, parents in Korea take part in the assessment of teacher performance. However, it is stated that parents receive special trainings to make quality contribution to the teacher evaluation system in this country. In a similar vein, parents have the power to assess teachers in Italy (Brog, 2018).

Teachers are people who help to boost national development and social peace and convey cultural values in society to future generations (Özden, 1999), shape the cognitive, affective and kinetic development and lifestyles of future generations, and influence the development of communication, research and creative skills (Erginer, 1995, 34; as cited in 
Tok, 1997). Akyüz (2012, p.2) cites the following summary about the teaching profession from a book on educational sociology and pedagogy: "Teaching is a profession of helping like nursing. Teachers commit themselves to their students for improving their abilities to the full extent. It is a highly respected feeling to be a teacher and say 'I am a teacher'." Also in Turkey, teaching should be the primary profession that deserves to achieve a prestigious place in society and maintain this prestige, and teachers should be able to say easily "I am a teacher" and feel respected in society.

In review of the relevant domestic literature, it was found that the scientific studies on the teaching profession mostly deal with teacher training, development and employment. The relative scarcity of the studies on the prestige of teachers and aimed at the appraisal of their professional status points out the need for further scientific studies in this context in literature. Ozankaya (2002) indicates that one of the primary problems of the Turkish education system is the decreased social prestige of the teaching profession and it will not be possible for education to develop and contribute to social economic development unless the prestige of the profession can attract young talents and keep them in the profession. The prestige of a profession is linked to how its member and society evaluate that profession. A person's assessment of the profession they perform in terms of prestige can be considered as an indicator of their commitment to that profession, job satisfaction, professional perception, professional efficiency and professional expectations. Accordingly, the findings obtained from this study which aimed to discuss how teachers assess the social prestige of their profession in Turkey will give an idea about the professional perceptions of teachers and reflect their expectations and needs which will help to increase their professional commitment. These findings can pave the way for the recommendations, proposed by the members of the teaching profession to increase the prestige of the profession and help teachers feel more valued, to be used as a reference in the regulations to be made by the authorities.

\section{Method}

\subsection{Research Model and Participants}

This study was conducted by using the phenomenology pattern, which is a qualitative research method. This approach attempts to define what many individuals experience in relation to a particular community or phenomenon (Creswell, 2007; Finlay, 2009). In this research, the concept 'prestige of the teaching profession in Turkey' is discussed as a phenomenon. Deep and detailed information about this phenomenon has been obtained by benefiting from the professional experiences of the participating teachers. The study group consisted of 674 teachers. The participants were recruited on voluntary basis. They were selected using the maximum variation sampling method, which is among purposeful sampling methods that are compatible with the qualitative research tradition. Therefore, variation was determined according to the institution, level of teaching, school location, experience and gender.

Table 1. Demographic information about the teachers in the study group

\begin{tabular}{|c|c|c|}
\hline Variables & & $\mathrm{f}$ \\
\hline \multirow[t]{4}{*}{ Level of teaching } & Preschool $(\mathrm{P})$ & 124 \\
\hline & Primary school (PS) & 235 \\
\hline & Secondary school (SS) & 129 \\
\hline & High school (HS) & 186 \\
\hline \multirow[t]{2}{*}{ Institution } & Public school & 373 \\
\hline & Private school & 301 \\
\hline \multirow[t]{4}{*}{ School location } & Village & 163 \\
\hline & Town & 121 \\
\hline & District centre & 110 \\
\hline & Provincial centre & 280 \\
\hline \multirow[t]{3}{*}{ Experience } & $1-9$ years & 250 \\
\hline & $10-19$ years & 195 \\
\hline & $20+$ years & 229 \\
\hline \multirow[t]{2}{*}{ Gender } & Female & 324 \\
\hline & Male & 350 \\
\hline
\end{tabular}

\subsection{Data Collection Tools}

The study data was collected through interview method and a semi-structured interview form was used as data collection tool. When preparing the interview questions, domestic and foreign literature on the prestige of teachers was reviewed, and then, 6 open-ended questions were determined. The questions were assessed by 2 experts studying Turkish education history, teacher training and comparative education and 2 classroom teachers in terms of aim, meaning and scope, and the interview form was finalized. The questions addressed to the teachers as part of the study are as follows:

1) Do you think that teaching is a prestigious profession in Turkey?

2) Does the prestige of the teaching profession; 
a. varies across regions with different socio-economic characteristics in Turkey?

b. varies across institutions (public school-private school) in Turkey?

c. varies across the level of teaching in Turkey?

3) What are your recommendations for increasing the prestige of the teaching profession in Turkey?

\subsection{Data Analysis}

In line with the aim of the study, content analysis was performed on the data by the researcher and an expert, individually. For that purpose, interview records were transcribed, data was coded, themes were created to collect these codes under certain categories, and the data was organized and defined according to the themes. To increase the validity of the study; 1) following data collection process, the researcher summarized the data and received the participants' views concerning the accuracy of the data, 2) the researcher and expert tested the consistency and significance of the findings constantly and questioned whether the categories constitute a significant whole, 3 ) the whole process from the selection of research sample to data analysis was explained in detail. The reliability of the content analysis was tested using the formula developed by Miles and Huberman (1994) Reliability = Consensus/ (Consensus+ Dissidence) and the reliability of the study was found $93.87 \%$ on average based on all the questions.

\section{Results}

Table 2 presents the participants' views on the question "Do you think that teaching is a prestigious profession in Turkey?"

Table 2. The prestige of the teaching profession in Turkey

\begin{tabular}{|c|c|c|c|c|c|c|c|}
\hline Categ. & $\mathbf{f}$ & $\%$ & Themes & Codes & $\mathbf{n}$ & $\mathbf{f}$ & $\%$ \\
\hline \multirow{16}{*}{ No } & \multirow{16}{*}{553} & \multirow{16}{*}{82} & \multirow{5}{*}{$\begin{array}{l}\text { Reasons arising from } \\
\text { education policies }\end{array}$} & Teachers have difficulty in being appointed (by the government). & 553 & 397 & 71.7 \\
\hline & & & & Education system undergoes radical changes in short time periods. & 553 & 283 & 51.2 \\
\hline & & & & $\begin{array}{l}\text { People lacking professional skills can be involved in teaching } \\
\text { process. }\end{array}$ & 553 & 174 & 32 \\
\hline & & & & There is a status difference between teachers who get appointed. & 553 & 156 & 27.6 \\
\hline & & & & Education system is undergoing a rapid privatisation. & 553 & 12 & 2.1 \\
\hline & & & \multirow{2}{*}{$\begin{array}{l}\text { Reasons arising from } \\
\text { CoHE }\end{array}$} & Base points for education faculties are low. & 553 & 162 & 29.3 \\
\hline & & & & Education faculties are high in number. & 553 & 109 & 19.7 \\
\hline & & & \multirow[t]{3}{*}{$\begin{array}{l}\text { Reasons arising from } \\
\text { MoNE }\end{array}$} & $\begin{array}{l}\text { It is currently discussed to allow students and parents to assess } \\
\text { teacher performance. }\end{array}$ & 553 & 285 & 52 \\
\hline & & & & Efforts to increase teacher motivation are not adequate. & 553 & 15 & 2.7 \\
\hline & & & & Teachers are not supported enough by the MoNE. & 553 & 1 & .2 \\
\hline & & & Economic reasons & Financial income is low in the teaching profession. & 553 & 180 & 33 \\
\hline & & & \multirow[t]{3}{*}{$\begin{array}{l}\text { Reasons arising from the } \\
\text { education system }\end{array}$} & $\begin{array}{l}\text { A student-centred education approach is implemented in the } \\
\text { teaching and learning process. }\end{array}$ & 553 & 41 & 7.4 \\
\hline & & & & The contents of the courses are being reduced. & 553 & 37 & 6.7 \\
\hline & & & & $\begin{array}{l}\text { It is compulsory to allow all students pass a grade in primary } \\
\text { education. }\end{array}$ & 553 & 30 & 5.4 \\
\hline & & & Social reasons & The significance attached to social values has been declining. & 553 & 34 & 6.1 \\
\hline & & & $\begin{array}{l}\text { Reasons arising from } \\
\text { working conditions }\end{array}$ & $\begin{array}{l}\text { Working conditions (insufficient physical structures in schools and } \\
\text { classrooms, crowded classrooms etc.) cannot be improved. }\end{array}$ & 553 & 15 & 2.7 \\
\hline \multirow{3}{*}{ Partly } & \multirow{3}{*}{84} & \multirow{3}{*}{12.5} & \multirow{3}{*}{$\begin{array}{l}\text { Reasons arising from } \\
\text { diverse variables }\end{array}$} & $\begin{array}{l}\text { Social prestige of the teaching profession varies according to } \\
\text { teachers' respect for their profession. }\end{array}$ & 84 & & 48.8 \\
\hline & & & & $\begin{array}{l}\text { Social prestige varies according to the location where the } \\
\text { profession is performed. }\end{array}$ & 84 & 40 & 47.6 \\
\hline & & & & Social prestige varies according to the level of teaching. & 84 & 13 & 15.4 \\
\hline \multirow[b]{2}{*}{ Yes } & \multirow[b]{2}{*}{37} & \multirow[b]{2}{*}{5.5} & \multirow[t]{2}{*}{ Social reasons } & Teaching is one of these professions that give trust to people. & 37 & 21 & 56.7 \\
\hline & & & & Turkish society is sensitive to teachers' problems. & 37 & 16 & 43.3 \\
\hline
\end{tabular}

According to Table $2,82 \%$ ( $\mathrm{f}=553$ ) of the participants stated that teaching is not a prestigious profession in Turkey. One of the teachers tried to display how bad the situation is, stating that "I do not think teaching is a prestigious profession in Turkey. As a matter of fact, teachers are subject to disrespect and harassed in many provinces." (SS6). Under the theme "Reasons arising from education policies", the majority of the teachers ( $\mathrm{f}=397,71.7 \%)$ reported that the main factor for loss of prestige in the profession is problems faced in getting appointed, and therefore, teachers either become unemployed or have to work in other sectors with low wages and status. One teacher expressed that "...as teachers cannot be appointed (by the government), they are employed at low paying jobs and enslaved by private institutions, or 
most teacher candidates work as waiter, driver, peddler or stallholder. For these reasons, teaching is not a prestigious profession in Turkey." (PS6). Under the same theme, 283 teachers (51.2\%) expressed their views under the code "Education system undergoes radical changes in short time periods." These teachers remarked that Turkey does not have a well-established and national education system, thus, the desired outcomes are not achieved in the field of education, and teachers are blamed for failure, adding that this situation resulted in loss of prestige for the profession. HS55 said that: "As every regime, every leader and every new government in Turkey starts to design (the country) with the education system, the foundation of the profession cannot be consolidated, and they try to build every change on wreckage. Teachers are held responsible for every negativity in education...". Teachers who expressed their views in relation to the code "People lacking professional skills can be involved in teaching process." ( $\mathrm{f}=174,32 \%)$ criticised that people with no professional teaching skills are involved in teaching process, stating that everyone with expertise in other fields can become a teacher easily in Turkey. Some of the teacher views under this theme are as follows: "The prestige of teaching profession is very low in Turkey, because it is perceived as a profession that can be performed by anyone. This perception was further strengthened with the fact that people with different backgrounds such as high school graduate, agricultural engineer or veterinarian were recruited as teachers in the past... (P21)"; "The profession has lost its previous status, because everybody can become a teacher under the name of contract teaching." (SS23). Another striking finding concerning the theme "Reasons arising from education policies" was that 156 participants ( $\mathrm{f}=156 ; 27.6 \%$ ) indicated the reason for loss of prestige in the teaching profession in Turkey is the existence of a status difference between the teachers appointed. One of the teachers who criticised that teachers who have completed their education and training process under almost the same circumstances and have similar standards get appointed with different employee rights said that "...discrimination has arisen between teachers as result of the recruitment of contract teachers. Even this has changed the perspective of Turkish society toward teachers..." (PS210).

As is seen in Table 2, teacher views under the theme "Reasons arising from the CoHE" were collected under two codes. The participants who expressed their views under the code "Base points for education faculties are low" ( $\mathrm{f}=162,29.3 \%)$ said that the CoHE needs to revise the requirements for becoming a teacher, the first requirement to be revised and regulated is base points for education faculties as the teacher training institutions, and the CoHE must absolutely raise these points. The teachers who responded in line with the theme "Education faculties are high in number" ( $\mathrm{f}=109$, 19.7\%) stated that there are too many teacher training institutions across the country, and the CoHE should make arrangements to prevent the opening of education faculty in every new university. Some of the teacher views under this theme are as follows: “...yes, everyone can become a teacher, because it is too easy to enter education faculty. Let's see, when the CoHE raises the base points, how many people will prefer teaching? When it gets difficult to get into education faculty, the prestige of the teaching profession will also increase..." (SS105); “... the CoHE should reduce the number of education faculties urgently. Only certain universities should have education faculty. When this is the case, the quotas for education faculties will also decrease. Many people will want to prefer teaching as a major, but will not be able to enter an education faculty and the profession will be more prestigious." (P83).

The analysis of Table 2 demonstrates that the majority of the teachers under the theme "Reasons arising from the MoNE" ( $\mathrm{f}=285,52 \%$ ) expressed their views in line with the code "It is currently discussed to allow students and parents to assess teacher performance." Saying that students and parents have every authority on the teacher and teachers are almost the slaves of students in the education and training process, these teachers expressed their response to the action plan announced by ministerial officials for "development of a compulsory performance evaluation system for all teachers" through which teacher performance will be assessed by parents and students. Regarding the subject, a teacher said: "Teaching profession has lost its previous status. Rating and evaluating teachers cause students and parents not to take into consideration teachers. How will students, in particular, evaluate their teachers? According to grades given by the teacher, or by saying that 'my teacher deserves 100 points as he has worked a lot'? How soon did the people who made this decision forget their student days..." (SS14).

Under the theme "Economic reasons", 180 teachers ( $\mathrm{f}=180 ; 33 \%)$ reported that one of the factors for loss of prestige in teaching profession is the insufficiency of teacher salaries. Accordingly, the teacher view is as follow: "...since its economic return does not meet the effort, teaching is perceived as an ordinary, easy profession that can be performed by anyone." (PS116).

The majority of the teachers who responded under the theme "Reasons arising from the education system" ( $\mathrm{f}=41,7.4 \%)$ criticised student-centred practices in the education system, and asserted that this system undermines teacher authority in classroom and ends their duty of "teaching". Accordingly, SS6 remarked that: "As teaching is of secondary importance in the student-centred system, teacher's duty as instructor is to show up in the class and keep children in the classroom. As the teacher is slave of students, the profession has lost its value.".

Table 2 demonstrates that social factors play a role in teachers' view that "Teaching is a prestigious profession in Turkey". According to the Table, about $\% 57(\mathrm{f}=21)$ of these teachers stated that society has more trust in the 
practitioners of this profession while the remaining $43.3 \%$ ( $\mathrm{f}=16)$ remarked that Turkish citizens display a sensitive attitude toward numerous problems of teachers such as transfer to another institution, appointment to another school, etc. - notably appointment to the profession.

Table 3 provides the distribution of teacher views on the question "Do you think that teaching is a prestigious profession in Turkey?" based on demographic characteristics.

Table 3. Distribution of teacher views according to demographic characteristics

\begin{tabular}{|c|c|c|c|c|c|c|c|}
\hline \multicolumn{2}{|c|}{ Demographic characteristics } & \multicolumn{2}{|c|}{ Yes } & \multicolumn{2}{|c|}{ Partly } & \multicolumn{2}{|c|}{ No } \\
\hline & & $\mathrm{f}$ & $\%$ & $\mathrm{f}$ & $\%$ & $\mathrm{f}$ & $\%$ \\
\hline \multirow[t]{5}{*}{ Level of teaching } & Preschool $(\mathrm{P})$ & 10 & 27 & 34 & 40.4 & 80 & 14.4 \\
\hline & Primary school (PS) & 5 & 13.5 & 31 & 36.9 & 199 & 36 \\
\hline & Secondary school (SS) & 8 & 21.6 & 17 & 20.2 & 104 & 18.8 \\
\hline & High school (HS) & 14 & 37.9 & 2 & 2.4 & 170 & 30.7 \\
\hline & Total & 37 & 100 & 84 & 100 & 553 & 100 \\
\hline \multirow[t]{3}{*}{ Institution } & Public school & 24 & 64.8 & 56 & 66.7 & 321 & 58 \\
\hline & Private school & 13 & 35.2 & 28 & 33.3 & 232 & 42 \\
\hline & Total & 37 & 100 & 84 & $\mathbf{1 0 0}$ & 553 & 100 \\
\hline \multirow[t]{5}{*}{ School location } & Village & 15 & 40.5 & 36 & 42.8 & 112 & 20.2 \\
\hline & Town & 13 & 35.1 & 27 & 32.1 & 81 & 14.6 \\
\hline & District centre & 6 & 16.3 & 14 & 16.6 & 90 & 16.2 \\
\hline & Provincial centre & 3 & 8.1 & 7 & 8.3 & 270 & 48.8 \\
\hline & Total & 37 & 100 & 84 & 100 & 553 & 99.8 \\
\hline \multirow[t]{4}{*}{ Experience } & $0-9$ years & 7 & 18.9 & 24 & 28.6 & 219 & 39.6 \\
\hline & $10-19$ years & 29 & 78.3 & 27 & 32.1 & 139 & 25.1 \\
\hline & $20+$ years & 1 & 2.8 & 33 & 39.3 & 195 & 35.2 \\
\hline & Total & 37 & 100 & 84 & 100 & 553 & $\mathbf{1 0 0}$ \\
\hline \multirow[t]{3}{*}{ Gender } & Female & 22 & 59.5 & 37 & 44 & 265 & 47.9 \\
\hline & Male & 15 & 40.5 & 47 & 56 & 288 & 52.1 \\
\hline & Total & 37 & 100 & 84 & 100 & 553 & 100 \\
\hline
\end{tabular}

According to Table 3, the majority of the participants who cannot see teaching as a prestigious profession ( $\mathrm{f}=553)$ consists of male teachers $(\mathrm{f}=288 ; 52.1 \%)$. Among them, $58 \%$ ( $\mathrm{f}=321$ ) work at public schools, $36 \%$ ( $\mathrm{f}=199)$ at primary school, about $49 \%(\mathrm{f}=270)$ at provincial centre, and $39.6 \%(\mathrm{f}=219)$ have an experience of $0-9$ years.

Table 4 presents the teachers' views regarding the question "Does the prestige of the teaching profession varies across regions with different socio-economic characteristics in Turkey?"

Table 4. Prestige of the teaching profession across regions with different socio-economic characteristics in Turkey

\begin{tabular}{|c|c|c|c|c|c|c|c|c|}
\hline ateg. & $\mathbf{f}$ & $\%$ & Themes & f & $\%$ & Codes & f & $\%$ \\
\hline \multirow{6}{*}{ Yes } & \multirow{6}{*}{590} & \multirow{6}{*}{87.5} & \multirow{2}{*}{$\begin{array}{l}\text { Teaching is a more } \\
\text { prestigious profession } \\
\text { in the eastern Turkey. }\end{array}$} & \multirow[t]{2}{*}{330} & \multirow[t]{2}{*}{55.9} & $\begin{array}{l}\text { Families' income level differs between the east and } \\
\text { west of the country. }\end{array}$ & 247 & 74.8 \\
\hline & & & & & & $\begin{array}{l}\text { There are different conditions (geographical, } \\
\text { climatic, urbanization, industrialization, school and } \\
\text { family opportunities, etc.) between the east and } \\
\text { west of the country. }\end{array}$ & 183 & 55.4 \\
\hline & & & \multirow{2}{*}{$\begin{array}{l}\text { Teaching is a more } \\
\text { prestigious profession } \\
\text { in the western Turkey. }\end{array}$} & \multirow[t]{2}{*}{3} & \multirow[t]{2}{*}{.5} & $\begin{array}{l}\text { The professional experience of teachers working in } \\
\text { eastern areas is not sufficient. }\end{array}$ & 2 & 66.6 \\
\hline & & & & & & $\begin{array}{l}\text { The prestige of teaching is not affected by } \\
\text { professional success in eastern areas. }\end{array}$ & 1 & 33.3 \\
\hline & & & \multirow{2}{*}{$\begin{array}{l}\text { Teaching is a more } \\
\text { prestigious profession } \\
\text { in rural areas. }\end{array}$} & \multirow[t]{2}{*}{257} & \multirow[t]{2}{*}{43.6} & Rural population's need for education is greater. & 256 & 99.6 \\
\hline & & & & & & $\begin{array}{l}\text { The level of education in local population affects } \\
\text { the prestige of the teaching profession. }\end{array}$ & 1 & .4 \\
\hline \multirow[b]{2}{*}{ No } & \multirow[b]{2}{*}{84} & \multirow[b]{2}{*}{12.5} & Teaching profession & \multirow[b]{2}{*}{84} & \multirow[b]{2}{*}{100} & Education is not given due importance in Turkey. & & \\
\hline & & & $\begin{array}{l}\text { has lost prestige } \\
\text { throughout the country. }\end{array}$ & & & & 80 & 95.2 \\
\hline
\end{tabular}

According to Table 4, 87.5\% ( $\mathrm{f}=590)$ of the respondents stated that the prestige of the teaching profession varies across regions with different socio-economic characteristics in Turkey. $4 \%$ of the teachers who answered "Yes" $(\mathrm{n}=24)$ said they worked in four regions in Turkey, $56 \%(\mathrm{n}=330)$ both in eastern and western Turkey and $20 \%(\mathrm{n}=118)$ in one 
region (east/west). This information indicates that the teachers who worked only in the east or west of the country as well as those who worked both in the east and west consider that professional prestige varies across regions with different socio-economic characteristics. The teachers who expressed their views under the theme "Teaching is a more prestigious profession in the east of the country." said that teaching is a more respected profession in society in the less developed eastern areas compared to western areas. One of the teacher views as follows: "I think, yes. Teaching profession is more respected in our eastern areas. Students in the west are more insolent ..." (P107); "Prestige declines as we go from the east to the west." (HS59). About 75\% of the teachers who were supportive of this view reasoned that families' income level differs greatly between the east and west. They added that in the eastern part consisting of mostly low-income families, families mainly encourage their children to enter public service -notably teaching- in various institutions since it provides regular income. One teacher stated that "The west enjoys a high economic status. A family of western origin does not easily want their kid to become a teacher. Eastern people want so because civil servants get paid regularly every month. Regions enjoying high economic status see the teacher as a means. (HS27). Under the same theme, 55\% of teachers commented that conditions (geographic, climatic, urbanisation, industrialisation, opportunities and means of schools and families, etc.) differ between the east and west of the country, which is projected in the teaching profession indirectly, and the profession is considered more sacred in the eastern Turkey that has inadequate conditions compared to the western part. A teacher (P64) expressed that "It definitely differs considerably between the east and west. First of all, training provided by a teacher in a village in the eastern Turkey is limited in means and opportunities. Teachers in the western Turkey are more comfortable in every respect. Thus, the profession is more respected in the east; teacher is a mother, father and sacred in the east...". Almost all teachers who opined under the theme "Teaching is a more prestigious profession in rural areas" $(99.6 \%, \mathrm{f}=256)$ stated that the prestige accorded to the profession varies according to the educational needs of people, the need for education is greater in rural population than urban population, and thus, teaching profession has maintained its prestige in rural areas. One teacher remarked that "When I was teaching in a village last year, I was more valued by my students, their parents and villagers, because people wanted education, loved school and was struggling so that children can learn something and improve themselves. I was important since I was training them. Now, I am in the city centre and clearly feel that I am less valued." (PS39).

According to Table 4, nearly 13\% ( $\mathrm{f}=84$ ) of the participants indicated that the status of the teaching profession does not vary across regions with different socio-economic characteristics because the profession has lost prestige throughout the country. Some teachers said that "Teachers face the same problems and challenges, and are not given due consideration in almost everywhere." (SS16); "Deterioration in the teacher status does not differ significantly across regions. I used to teach in Aydin and now I am in Kars. I came to the easternmost part of Turkey from the westernmost part, but have not seen huge differences in terms of professional prestige in both cities." (HS7). 95\% of them ( $\mathrm{f}=80)$ also attributed loss of prestige in the profession to the value accorded to education in Turkey, which is diminishing gradually.

Table 5 presents the teachers' views concerning the question "Does the prestige of the teaching profession varies across institutions in Turkey?"

Table 5. Prestige of the teaching profession across institutions in Turkey

\begin{tabular}{|c|c|c|c|c|c|c|c|c|}
\hline Cat & f & $\%$ & Themes & f & $\%$ & Codes & $\mathbf{f}$ & $\%$ \\
\hline \multirow{4}{*}{ Yes } & \multirow[t]{4}{*}{621} & \multirow[t]{4}{*}{92.1} & \multirow{4}{*}{$\begin{array}{l}\text { Teachers in public } \\
\text { schools have higher } \\
\text { professional prestige. }\end{array}$} & \multirow{4}{*}{621} & \multirow{4}{*}{100} & Pay difference & 541 & 86.6 \\
\hline & & & & & & Job guarantee & 419 & 67.4 \\
\hline & & & & & & Working hours & 403 & 64.8 \\
\hline & & & & & & Parent-teacher relationship & 397 & 63.9 \\
\hline No & 53 & 7.9 & $\begin{array}{l}\text { Teaching profession has } \\
\text { lost prestige throughout } \\
\text { the country. }\end{array}$ & 53 & 100 & $\begin{array}{l}\text { Today, teacher training is not given } \\
\text { due importance. }\end{array}$ & 53 & 100 \\
\hline
\end{tabular}

The analysis of Table 5 reveals that $92 \%$ of the participants stated that the prestige of the teaching profession varies across institutions in Turkey and this difference is in favour of public schools. Some of these views are as follows: "Teachers' prestige varies across Turkey, because teaching is divided into two as teaching in the private sector and teaching in the public sector. Teachers in public schools enjoy slightly more prestige. Teachers in the private sector are being treated as doormat." (PS50); "...the sector is divided into two: private and the MoNE. While teachers employed by the MoNE are comfortable and less productive, they are accorded more respect." (SS114). About 87\% ( $\mathrm{f}=541$ ) of teachers who considered that teachers in public schools have a more prestigious status in society said that the main factor causing this situation is "pay difference", and the salaries of teachers in private schools are not satisfactory. About $67 \%$ of the teachers $(\mathrm{f}=419)$ indicated that private schools do not provide job security to teachers; 65\% ( $\mathrm{f}=403$ ) remarked that public schools have less working hours; and 64\% ( $\mathrm{f}=397)$ said that the relationship between parents and teachers is more formal in public schools, emphasizing that these variables affect the social status of the teaching profession. Some of these views are as follows: "...unfortunately, the government simply has turned its back on 
teachers in the private sector. While working hours and salaries of the teachers in private schools are even against human rights, it is rather meaningful that no one implements the inspection mechanism." (PS67); "If you work at public sector, you have job guarantee. Turkish people respect guaranteed jobs. There is the fear of getting fired every year in the private sector. Teachers feel this fear and reflect it to their environment. Besides, the private sector has heavy workload, offers no money, and parents can talk to you as if they talk to their kids, not a teacher, or they can even scold you." (HS73).

According to Table 5, it is seen that the views of all teachers who commented in "no" category ( $\mathrm{f}=53$ ) were collected under the code "Today, teacher training is not given due importance". The teachers stated that regardless of the institution they perform their profession; they are not respected, because the problem is not the institutions they work at, but the teacher training system. One of the teachers expressed that "Does it matter it is public or private? There is no prestige anyway, so there is no difference between institutions. Unfortunately, we cannot raise good teachers. We need to raise idealist teachers of the old school. Teachers who like their profession and love their country under any circumstances whatsoever..." (P93).

Table 6 presents the teachers' answers to the question "Does the prestige of the teaching profession varies across the level of teaching in Turkey?"

Table 6. Prestige of the teaching profession across the level of teaching in Turkey

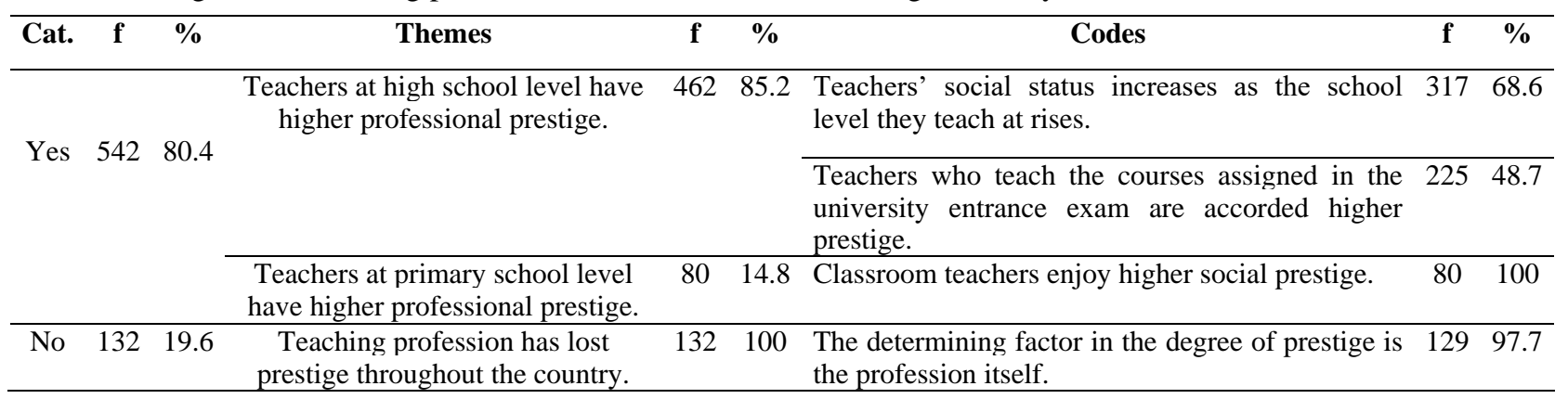

When Table 6 was analysed, it was found that $80.4 \%$ ( $\mathrm{f}=542$ ) of the respondents said that the status of the teaching profession varies across the level of teaching in Turkey. Accordingly, about $85 \%$ of the teachers reported that teachers at high school level have higher professional prestige. 317 ( $\mathrm{f}=371,68.6 \%)$ respondents stated that the Turkish society attaches higher status to teachers at high school level and thinks that they have a higher level of knowledge; thus, these teachers are accorded more respect. One participant, P18 expressed that "...I think high school teachers are respected more, because they teach in high school, they know more (!)...”. In this regard, 225 teachers $(\mathrm{f}=225,48.7 \%)$ indicated that status of high school teachers also differs depending on their field. One of them stated that "Let alone institutions, there is a status difference even between fields. While the courses needed to pass exams and teachers giving these courses are more valued in society, other courses and teachers are trivialised and made insignificant unfortunately." (SS61).

All teachers who commented in line with the theme "Teachers at primary school level have higher professional prestige" ( $\mathrm{f}=80, \% 100)$ stated that almost everyone remembers the name of their classroom teacher easily, get into touch/would like to get into touch with them on special days, and thus, classroom teachers enjoy a higher status in society.

Under "no" category, 132 teachers (19.6\%) indicated that in the Turkish society, the main factor determining the degree of prestige is a person's profession, and level of teaching does not matter. One participant said that: "There is no difference, because they ask us what our job is, and we answer that "I am a teacher". We do not say "I am a primary school teacher or high school teacher". For example, banks do not grant higher loans to high school teachers..." (PS29).

The analysis of Table 7 reveals that $92 \%$ of the teachers recommended that "Efforts should be made to increase social awareness about the significance of the teaching profession." Asserting that teaching is among the most important professions that shape the future of society and also raises qualified individuals, the participants added that it is the primary profession that deserves prestige. About $92 \%$ of the respondents said that increasing the professional prestige of teaching requires increase in salaries while $89.5 \%$ stressed the need for appointing more teachers. A striking finding in Table 10 is that teacher views are in line with the answers they suggested for other sub-problems of the study. The views of some of the teachers are as follows: "Education and hence, teachers must be given due prestige, both financially and morally, so that the society can have a bright future. To that end, social awareness about the subject should be increased. Children should not have the luxury of assessing their teachers. The ministry should give the teacher full 
support. Equal pay for equal work policy should be implemented." (P116); "For those who want to become a teacher, their skills in addition to their university entrance exam should be assessed. For example, leadership, openness to novelty, self-expression, public speaking even if it is in a small group, making people listen to yourself, etc." (SS17); "Discrimination between teachers should be ended by granting tenure to contract teachers. Teacher salaries should be increased. Contract teaching should be abolished. Teachers in the eastern Turkey should be granted privileges, and the profession should not be exposed to political pressures." (HS123).

Table 7 demonstrates teachers' answers to the question "What is your recommendation for increasing the prestige of the teaching profession in Turkey?"

Table 7. Teacher recommendations to increase the prestige of the teaching profession in Turkey

\begin{tabular}{|c|c|c|c|c|}
\hline Themes & Codes & $\mathbf{n}$ & $\mathbf{f}$ & $\%$ \\
\hline Social recommendations & $\begin{array}{l}\text { Efforts should be made to increase social awareness about the } \\
\text { significance of the teaching profession. }\end{array}$ & 674 & 621 & 92.1 \\
\hline \multirow{5}{*}{ Increase motivation } & $\begin{array}{l}\text { Compulsory performance evaluation system for all teachers should } \\
\text { be removed from the agenda. }\end{array}$ & 674 & 301 & 44.7 \\
\hline & MoNE should be more sensitive toward teachers' problems . & 674 & 90 & 13.3 \\
\hline & Teacher complaint lines should be closed. & 674 & 25 & 3.7 \\
\hline & $\begin{array}{l}\text { Teachers who are successful in their jobs should be given awards of } \\
\text { sentimental value. }\end{array}$ & 674 & 19 & 2.8 \\
\hline & $\begin{array}{l}\text { Legal arrangements should be made to protect teachers from sexual } \\
\text { harassment. }\end{array}$ & 674 & 1 & .1 \\
\hline \multirow{7}{*}{ Teacher training } & Efforts should be made to increase quality in teacher training system. & 674 & 380 & 56.4 \\
\hline & Some education faculties should temporarily stop enrolling students. & 674 & 480 & 71.2 \\
\hline & $\begin{array}{l}\text { The quotas in education faculties should be determined according to } \\
\text { teacher shortage. }\end{array}$ & 674 & 453 & 67.2 \\
\hline & $\begin{array}{l}\text { Students who prefer education faculties should take professional } \\
\text { skills test. }\end{array}$ & 674 & 385 & 57.1 \\
\hline & $\begin{array}{l}\text { Pedagogical formation programs should be restricted to certain } \\
\text { faculties and with quotas. }\end{array}$ & 674 & 164 & 24.3 \\
\hline & Base points for education faculties should be raised. & 674 & 224 & 33.2 \\
\hline & Teachers should be given training on curricular changes. & 674 & 1 & .1 \\
\hline \multirow{5}{*}{ Education policy } & A higher number of teachers should be appointed. & 674 & 603 & 89.5 \\
\hline & The status difference in teacher appointments should be eliminated. & 674 & 201 & 29.9 \\
\hline & A national education policy should be established. & 674 & 188 & 27.9 \\
\hline & Contract teaching should be abolished. & 674 & 122 & 18.1 \\
\hline & $\begin{array}{l}\text { Teachers working in the eastern Turkey and rural areas should be } \\
\text { granted various privileges. }\end{array}$ & 674 & 542 & 80.4 \\
\hline Income status of & Teachers' salaries should be increased. & 674 & 618 & 91.7 \\
\hline \multirow{4}{*}{ Educational regulations } & Teachers' powers within school and classroom should be increased. & 674 & 346 & 51.3 \\
\hline & $\begin{array}{l}\text { Throughout the country, physical conditions and educational } \\
\text { equipments in the schools should have similar standards. }\end{array}$ & 674 & 277 & 41.1 \\
\hline & $\begin{array}{l}\text { The primary education regulation should be revised to enable } \\
\text { students with a low level of achievement to repeat their grade. }\end{array}$ & 674 & 41 & 6.1 \\
\hline & $\begin{array}{l}\text { Steps should be taken to improve pay, job guarantee, work load, } \\
\text { relationship with parents-student, etc. for teachers at private schools. }\end{array}$ & 674 & 341 & 50.6 \\
\hline
\end{tabular}

\section{Discussion}

This study aiming to examine teacher views on the prestige of their profession in Turkey revealed that $82 \%$ of the participants do not view teaching as a prestigious profession in the country. A review of literature provides research findings suggesting that the prestige of the teaching profession has declined (e.g. Ünsal, 2018; Aydın, Demir \& Erdemli, 2016; Karaman, Acar, Kılınç, Buluş \& Erdoğan, 2013; Buchanan, 2010; Kamwengo, 2010; Hall \& Langton, 2006; Tok, 1997). These findings indicate that the prestige of the profession has gradually declined not only in Turkey but also in various parts of the world. When we analyzed the demographic distribution of the teacher views, we found that $87 \%$ of the teachers who had 0-9 experience in the profession made negative comments on the subject. This result demonstrates that the participants who mostly had not completed 10 years in the job had a negative perception about the social status of their profession. According to an OECD (2014) report, professional experience is highly important in evaluating the prestige of the teaching profession. The report indicates that in 13 OECD member countries, teachers with over 5 years of professional experience consider that they have less professional prestige in their societies than teachers with less experience. About $72 \%$ of the teachers thinking that their profession has lost prestige in Turkey pointed out employment policy for teaching as the reason for this situation. Employment problem of teacher candidates has an important place in terms of the social status of the profession. According to the data given in the Teacher Strategy Paper (2017), the number of college graduates who took Public Personnel Selection Examination, but could not get appointed was 
438.134 by 2016 while the number of graduates who were appointed was 49.015 . This data represents the rate of unemployed teachers in Turkey and causes a decrease in the value attributed to the profession in social perception.

The results of the study indicated that $52 \%$ declared that statements in the media regarding teacher performance evaluation system prompted concern among teachers and teacher candidates, and any arrangement that paved the way for the assessment of teacher performance by parents and particularly students will tarnish teachers' reputation, adding that it has a negative impact on the social status of the profession. Ingvarson \& Chadbourne (1994) assert that the most important source of an education system is teachers' knowledge and skills, and the main strategy to sustain and enhance this source is the assessment of teacher performance and improving teachers' professional career. Although the aim, scope and process of the performance evaluation system for teachers are well-defined in countries such as the UK, US, Australia and New Zealand, it has come to the forefront in Turkey in recent years. The MoNE (2018) announced that teachers will be evaluated by their colleagues, principals, parents, students, group teachers and themselves, i.e. via six channels. Participants of this study stated that especially parents and students in these groups do not have the competence to assess the teaching profession, and even if they do, such assessment cannot be fair. Indeed, a study by Soydan (2012) found that principals and teachers generally have negative judgments that a performance system in education can be implemented fairly. Another study by Akşit (2006) concluded that the participants were concerned since the performance evaluation process is subjective and biased while 56\% stated that they do not want the participation of parents in performance evaluation process. In his study, Odhiambo (2005) comes to the conclusion that $76.5 \%$ of participants do not want students assess their performance. The researcher reports that in literature, some teachers state that students should not be involved in the evaluation process as they are not qualified in terms of teaching and training techniques as well as evaluation.

This study found that $33 \%$ of the teachers who believe that teaching profession has lost its prestige in Turkey pointed out income insufficiency as the reason. Stating that professional prestige is directly proportionate to income level in Turkey, the respondents claimed that teaching profession has lower prestige as it is a low-income profession. The study "Work Life and Professional Prestige in Turkey" conducted by Dr. SUNAR demonstrates, similarly to the result of this study, that there is a relationship between professional prestige and professional income in Turkey, the most significant criterion for a job in our country is decent pay, and teaching profession is ranked as the fourth in prestige ranking after medical doctor, professor and judge (daily Hürriyet, 2018). Similar findings can also be found in foreign literature. For instance, Symeonidis (2015) indicates that there are various factors affecting the prestige of teachers in society, and the most important factors are pay, job guarantee and working conditions. A survey by Ogiegbaen \& Uwameiye (2005) of parents and prospective university students in Nigeria found that negative attitudes toward teaching profession are influenced by teachers' low status and poor, irregular payments. In their study on teachers, Osunde \& Izevbigie (2006) indicate that low and delayed pay resulted in teachers' losing sense of belonging, which had a negative impact on their professional status and esteem.

Another finding of this study that needs to be emphasized is that about $5 \%$ of the teachers expressing that teaching is not a prestigious profession in Turkey indicated this is a result of the student-centred education approach forming the basis of Turkish education system since the 2004-2005 academic year. The teachers $(\mathrm{f}=30 ; 5 \%)$ expressed that this approach damages teacher authority in classroom, causes them lose the role of "wise man" and makes students almost a partner in the "teaching" process that should belong to the teacher. They also think that the traditional teacher-centred education system should continue so that they do not lose their authority. This finding indicates that "the student-centred education as a pedagogical approach whose fundamental philosophy is to enable and enhance democracy, social justice, individual freedom, creativity and critical thinking, which aims to encourage students as self-motivated and independent learners, allows permanent and participatory learning, considers that interests, abilities, and experiences of all students are unique and valuable, and has roots based on humanism" (Bailey \& Colley, 2015; Ha, 2014; McDonough, 2012) still has not been sufficiently understood by some teachers for almost 14 years (2004-2018). Hence, a study by Arseven, Şahin \& Kılıç (2016) revealed that participants' adaptation level of student-centred education approach decreases from primary school to high school and teachers' perception of the practicability of student-centred education is not positive, and teachers still adopt a teacher-centred education approach in terms of "Planning," "Implementation" and "Assessment."

Our study found about $57 \%$ of the teachers who expressed a positive opinion as to the prestige of teaching in Turkey ( $\mathrm{f}=34$ ) think that Turkish people have trust in teachers while the remaining $43 \%$ believe that Turkish people are sensitive toward the problems of teachers. UNESCO's Global Education Monitoring Report (2017, p.71) presents a finding from a study that examined 21 countries' trust in teachers and education system. According to this finding, trust in teachers is greater than trust in education systems in the majority of these countries. The striking findings of the report on Turkey are as follows: Turkish public's trust in education system is about 4.5 on a scale of 10 while trust in teachers is about 6.5 . However, the report states that trust in the teaching profession does not necessarily mean a direct proportion to the prestige accorded to the profession. Thus, it is seen that the findings of this sub-dimension of the study are not compatible with the relevant literature. Burns and 
Darling-Hammond (2014) maintained that students achieve more permanent learning in countries where the teaching profession enjoys high professional prestige like Finland, Singapore and South Korea. In addition, teachers' positive perceptions toward their professional prestige are closely related to other aspects of quality education including continuing professional development, research, cooperation with colleagues and participation in decision-making processes in education and training (Hargreaves and Flutter, 2013; as cited Symeonidis, 2015). Hence, necessary steps should be taken to increase the number of teachers who have positive perceptions that the teaching profession enjoys high social status in Turkey.

Furthermore, the study found that about $88 \%$ of the respondents $(\mathrm{f}=590)$ think that the prestige of the teaching profession varies across regions with different socio-economic characteristics in Turkey. The majority of teachers who commented in favour of this view ( $\mathrm{f}=247 ; 74.8 \%$ ) stated that teaching profession is more prestigious in the eastern Turkey compared to the west, because the socio-economic development of people in the east is lower than those in the west; thus, families encourage their children to enter public service that provides a regular income such as teaching. In literature, we can find research findings suggesting that the income level of families is effective in preferring teaching as a profession. For instance, the studies by Yaman, Yaman \& Eskicumalı (2001), Saban (2003), Akbayır (2002) and Türkdoğan (2014) indicate that the teaching profession is mostly preferred by very low and middle income groups. In addition, $43.6 \%$ ( $\mathrm{f}=257$ ) reported that the teaching profession is more respected in rural areas. Almost all of the teachers $(\mathrm{f}=256,99.6 \%)$ who supported this view said that rural population's need for education is greater, teachers are primary people who can meet this need and hence, teaching profession has higher prestige for people living in the rural areas. In a similar vein, Polat, Kaysilı \& Aydin (2015) assert that the perception about teachers also changes depending on the environment people live in, teaching is perceived as an ordinary profession in big cities while the meanings attributed to the teaching profession is more positive and optimistic in the country - especially in villages - and teaching is even considered a sacred profession in such areas.

The study also found that the teachers who claimed that the prestige of teaching does not vary across areas with different socio-economic characteristics in Turkey $(\mathrm{f}=84 ; 12.5 \%)$ consider that education is not given due importance in Turkey. In the $21^{\text {st }}$ century called the information age, information and technology developing based on this information are important in terms of social development, and societies producing information can maintain and continue their existence in a competitive order. In societies that are aware of the significance of information production, the main aim of education systems is to raise "individuals who can learn" anytime, anywhere and at any age -due to the dynamic, dispersed and non-storable nature of information. In Turkey, a country advancing to become an information society, there are certain predicaments for the education system to raising individuals who can learn. These predicaments are categorized as the lack of a long term vision as the Turkish education system is influenced by bureaucratic structure; that radical changes in the system (philosophical changes, changes in curricula, changes in the exam system etc.) cannot represent the culture effectively; failure in solving problems related to the qualifications of students (readiness, choice of profession, personal differences etc.) teachers (training, appointment, status, pay, professional knowledge and skills, professional development, career progression etc.) and school administrators (training, selection etc.); failure in eliminating differences in the process of distributing education funding to regions, provinces, types and levels of education, individuals and groups in different socio-economic levels; problem of the status of public and private schools in education; and failure in solving the problems related to school structuring (stratification in education systems, social status and significance of vocational schools, transported education system, implicit messages of schools etc.) (Çeven \& Karakulle, 2018; Sarıbaş \& Babadağ, 2015; Kösterelioğlu \& Bayar, 2014; Özyılmaz, 2013; Uygun, 2013). These problems that have not been resolved in the Turkish education system for a long time and are unlikely to be resolved in the short term might have affected the society's perspective toward education and hence, to teachers, and caused loss of prestige for the teaching profession in social perspective.

The study also found that $92 \%$ of the participants consider that the prestige of teaching varies across institutions, and teachers in public schools enjoy higher professional prestige in comparison to those teaching in private schools. Some of these teachers stated that the factors causing this situation are pay difference, job guarantee, working hours and parent-teacher relationship; adding that teachers in public schools have a more respectable place in society since their salary is higher, they have job guarantee and more flexible working hours, the relationship between parents and teachers is more formal and parents put less pressure on teachers. In their study, Karaköse \& Kocabaş (2006) found that teachers in public schools think that working in a public school does not give them a significant prestige while teachers in private schools express that the reputation of these schools increase the prestige of their staff in society. The reason for this difference in the study results may be the reputation of private schools in their environment. If teachers are working in a private school that is appreciated and respected by the environment for the quality of education and teaching offered to learners, they might consider that teaching in this school increases their social prestige. Hence, there is a need for new studies on teachers in private schools so that the finding for this sub-problem of the study can be more valid. Such studies should ask teachers' views on the reputation of the private school they work at in their environment, and new studies should also ask teachers to assess the contribution of their school to social prestige of the profession. 
Finally, the study revealed that $80 \%$ consider that the professional prestige of teaching varies across the level of teaching in Turkey. Most of the teachers who supported this view expressed that high school teachers enjoy higher professional prestige ( $\mathrm{f}=462,85.2 \%$ ). Bek (2007) maintains that one of the factors influencing the social prestige of the teaching profession is the level of teaching and fields taught, the status of a high school teacher in Turkey is higher than that of a classroom teacher or teachers at lower levels, and Turkish society thinks that teachers at higher levels of teaching receive more training, have more income and are more knowledgeable. In addition, Hargreaves (2009) ranks the professional prestige scores of teachers and other professions according to the Standard International Professional Prestige Scales (1977-1996) and indicates that the score of high school teachers is higher than primary school teachers.

At the end of the study, the majority of the respondents recommended that steps should be taken to increase social awareness about the significance of teaching profession, teacher salaries should be increased and more teachers should be appointed in order to increase the prestige of teaching profession in Turkey. It was found that the teachers' recommendations were related to the elimination of the negative aspects they expressed for other sub-problems of the study. For example, a teacher who stated that teachers do not get enough support from the MoNE recommended for increasing the prestige of teaching profession that "Teachers who are successful in their jobs should be given awards of sentimental value."

In line with the findings of the study, the following recommendations can be made:

1. Turkish education system needs to adopt a visionary and national education policy that is far from bureaucratic pressures. Thus, public trust in education system and teachers can increase and the teaching profession can earn the prestige it deserves.

2. Increasing the share of education in government budget can enhance the quality of education system as well as allowing the participation of more teacher candidates in teaching process, and with the increase in teacher salaries, the prestige of the profession will increase in line with the direct proportion between pay and prestige according to the Turkish society.

3. The criteria for recruiting students to teacher training institutions in Turkey should be revised by a commission to be established in cooperation between the MoNE and CoHE. To that end, first of all, the quotas and base points of education faculties should be determined according to teacher shortage, and candidates who want to become a teacher should take certain tests such as ability, personality, expression and skill tests. Thus, it will be ensured that individuals who are committed to teaching profession and have the necessary competencies receive teacher training instead of individuals who want to become a teacher due to reasons such as family pressure, desire to have a regular income, obtaining a university entrance score that is sufficient for education faculties, etc. As a result, the qualifications of teachers and the efficiency of education will increase, and public respect for and trust in qualified teachers and quality education system will increase.

4. The MoNE should increase its support for teachers in such areas as professional development, teacher rights, initiatives and responsibilities and meeting training needs, etc., and take actions to make teachers feel secure and respected. To that end, the Ministry first needs to take the opinions of stakeholders in education such as academics, education unions and foundations about the performance evaluation system which is a nuisance for teachers, and by using multiple data sources, it should examine the practices in countries that evaluate teacher performance. In this context, the parties should be given comprehensive special training as in Korea so that such a practice of assessing teacher performance by parents and students and rating or grading the results can be implemented efficiently in Turkey. Accordingly, the Ministry of National Education, Ministry of Family and Social Policies and Council of Higher Education should come together and cooperate while parent information programs should be prepared and pilot studies should start as soon as possible. The frequency of in-service trainings on the student-centred education system should be increased, and teachers should be convinced that having students at the centre of education system does not mean that teachers stay in the background. It should be ensured that educational institutions have similar standards in every corner of the country, thus, the differences in terms of working conditions of teachers at schools in a socio-economically high income environment and of teachers at schools in a low income environment should be reduced. In addition, the status difference in teacher appointments (contract or permanent teachers) should be abolished, and legislative regulations should be made to ensure that all teachers have the same employee rights.

5. In contrast with literature, this study found a relationship between the trust in the teaching profession and the respect for this profession in Turkey. To enhance the validity of this finding, studies should be conducted to examine the relationship between the trust and prestige accorded to the teaching profession in Turkey. 


\section{References}

Akbayır, K. (2002). Role of the family in the orientation to teaching profession and the role of gender in branch selection. V. National Science and Mathematics Education Congress, 2, 1183-1188, Middle East Technical University, Turkey.

Akşit, F. (2006). Teachers' views on performance evaluation (Bigadic elementary teachers example). Journal of Social Sciences Research, 2, 76-101.

Akyüz, Y. (2006). A new and overall view to the first years of Darülmuallimîn (teacher training college) in the 160th anniversary of teacher training in Turkey. Ottoman Historical Research and Application Center, 20, 17-58. https://doi.org/10.1501/OTAM_0000000532

Aparicio, C. C., \& Arévalo, A. B. (2014). Teacher training system in Spain. In Pusztai, G., \& Engler, A. (Eds). Teacher education case studies in comparative perspective (pp 23-46). Debrecen: Center for Higher Education Research and Development.

Arseven, Z., Şahin, Ş., \& Kılıç, A. (2016). Teachers' adoptation level of student centered education approach. Journal of Education and Practice, 7(29), 133-144. https://files.eric.ed.gov/fulltext/EJ1118805.pdf

Aycan, Ş. (2015). Step back in educating high school teachers: From higher teacher education school to pedagogical formation course. MSKU Journal of Education, 2(2), 61-72. https://doi.org/10.21666/mskuefd.98757

Aydın, I., Demir, T. G., \& Erdemli, O. (2015). Teacher's views regarding the social status of the teaching profession. Anthropologist, 22(2), 146-156. https://doi.org/10.1080/09720073.2015.11891865

Bailey, G., \& Colley, H. (2015). Learner-centered' assessment policies in further education: Putting teachers time under pressure. Journal of Vocational Education \& Training, 67(2), 153-168. https://doi.org/10.1080/13636820.2014.983956

Başkan, G. A. (2001). Teaching profession and re-structuring in teacher education, Journal of Hacettepe University Faculty of Education, 20, 16-25.

Bek, Y. (2007). Teacher's social/professional roles and status. (Master's degree project), Trakya University Institute of Social Sciences, Edirne.

Brog, S. (2018). Teacher evaluation: Global perspectives and their implications for English language teaching a literature review. London: British Council.

Buchanan, J. (2010). May I be excused? Why teachers leave the profession. Asia Pacific Journal of Education, 30(2), 199-211. https://doi.org/10.1080/02188791003721952

Burns, D., \& Darling-Hammond, L. (2014). Teaching around the world: What can TALIS tell us? Stanford, CA: Stanford Center for Opportunity Policy in Education.

Carlo, A., Michel, A., Chabanne, J. C., Bucheton, D., Demougin, P., Gordon, J., Sellier, M., Udave, J. P., \& Valette, S. (2013). Study on Policy Measures to improve the Attractiveness of the Teaching Profession in Europe. Retrieved from http://ec.europa.eu/assets/eac/education/library/study/2013/teaching-pr ofession1_en.pdf

Çelikten, M., Şanal, M., \& Yeni, M. (2005). Teaching profession and features. Erciyes University Journal of the Institute of Social Sciences, 19(2), 207-237.

Çeven, S., \& Karakulle, İ. (2018). Information society and education, an overview of education in Turkey. Social Sciences Studies Journal, 4(14), 695-705. https://doi.org/10.26449/sssj.422

Council of Higer Education[CoHE] (1998). Rearrangement of teacher training programs in education faculties. Ankara: CoHE Publising.

Creswell, J. W. (2007). Qualitative inquiry \& research design: Choosing among five approaches. Thousand Oaks, CA: Sage.

Demirtaş, Z. (2007). Sibyan schools and organization of primary education during the ottoman period. Fırat University Journal of Social Science, 17(1), 173-183.

Finlay, L. (2009). Debating phenomenological research. Phenomenology \& Practice, 3(1), 6-25.

Ha, P. L. (2014). The politics of naming: Critiquing "learner-centered" and "teacher as facilitator" in English language and humanities classrooms. Asia-Pacific Journal of Teacher Education, 42(4), 392-405. https://doi.org/10.1080/1359866X.2014.956048

Hall, D., \& Langton, B. (2006). Perceptions of the status of teachers ministry of education. New Zealand: Ministry of 
Education.

Hargreaves, L. (2009). The status and prestige of teachers and teaching. In Saha, L. J. \& Dworkin A. G . (Eds.) International handbook of research on teachers and teaching (pp. 217-229). USA:Springer, Boston, MA. https://doi.org/10.1007/978-0-387-73317-3_13

Hürriyet Daily (2018, 25 June). Announced the most respected professions in Turkey, Retrieved from http://www.hurriyet.com.tr/galeri-iste-turkiyenin-en-itibarli-meslekleri-40364624?p=4

Ingvarson, L., \& Chadbourne, R. (1994). The career development model of teacher evaluation, In Ingvarson, L. \& Chadbourne, R. (Eds), Valuing teachers' work: New directions in teacher appraisal (pp 11-45).Melbourne: ACER.

Kamwengo, M. M. (2010). Perceptions of teaching as a profession as held by practicing teachers in selected high schools of Lusaka District.(Unpublished doctoral dissertation), The University of Zambia, Lusaka.

Karaköse T., \& Kocabaş İ. (2006). The effect of teachers' expectations on job satisfaction and motivation in private and public schools. Journal of Theory and Practice in Education, 2(1), 3-14.

Karaman, M., Acar, A., Kılınç, O., Buluş, U., \& Erdoğan, Ö. (2013). The status and dignity of the teaching profession according to the teachers working in the province of Sakarya, VI. National Graduate Education Symposium Proceedings Book, II, 104-111.

Karamustafaoğlu, O., \& Özmen, H. (2004). A research on the value given to the teaching profession in our society and teacher candidates, Journal of Values Education, 2(6), 35-49.

Kösterelioğlu, İ., \& Bayar, A. (2014). An assessment on recent issues of Turkish education system. The Journal of Academic Social Science Studies, 25(I), 177-187. https://doi.org/10.9761/JASSS2279

Larsen, M. (2006). Comparing Connecticut and Finland: Teacher friendly policies in an age of accountability. Canadian and International Education, 35(2),17-34.

McDonough, M. (2012). Applying learner-centered principles: From face to face instruction to a hybrid course learning format. Journal of Learning in Higher Education, 8(2), 31-39. https://files.eric.ed.gov/fulltext/EJ1145174.pdf

Miles, M. B., \& Huberman, A. M. (1994). Qualitative data analysis: An expanded Sourcebook. Thousand Oaks, CA: Sage.

Ministry of National Education [MONE] (2018). MoNE teacher performance evaluation and candidate teacher work and operations regulationdraft. Retrieved from http://yenibosnadogusanayiilkokulu.meb.k12.tr/icerikler/meb-ogretmenperformansdegerlendirme-ve-aday-ogretme nlik-is-ve-islemleri-yonetmeliktaslagi_4519285.html\#

MONE (2017). Teacher strategy document 2017-2023, Retrieved from http://oygm.meb.gov.tr/meb_iys_dosyalar/2017_06/09140719Strateji_Belgesi_Resmi_Gazete_sonrasY_ilan.pdf

Odhiambo, O. G. (2005). Teacher appraisal: The experiences of Kenyan secondary school teachers. Journal of Educational Administration, 43(4), 402-416. https://doi.org/10.1108/09578230510605441

OECD (2014). TALIS 2013 results: An International Perspective on Teaching and Learning. Paris: OECD Publishing. Retrieved from http://dx.doi. org/10.1787/9789264196261-en.

Ogiegbaen, S. E. A., \& Uwameiye, R. (2005). Analysis of factors influencing negative attitude toward teacher education in Nigeria. Education, 126(2), 292-303. https://eric.ed.gov/?id=EJ765678

Osunde, A. U., \& Izevbigie, T. I. (2006). An assessment of teachers' attitude towards teaching profession in midwestern Nigeria. Education, 126(3), 462-467. https://eric.ed.gov/?id=EJ765765

Ozankaya, Ö. (2002). The place and location of teachers in contemporary societies. Inönü University Journal of the Faculty of Education, 3(3), 63-80.

Özden, Y. (1999). Transformation in education, new values in education. Ankara: PegemA Publishing.

Özpolat, A. (2002). Sociological aspects of the teaching profession and the place of teachers in society according to teachers, students and parents perceptions: Zonguldak example. (Unpublished doctoral thesis). Istanbul University Institute of Social Sciences, Turkey.

Özyılmaz, Ö. (2013). The problems of Turkish national education system and search for solutions, Ankara: Pegem Publishing.

Polat, Ü., Kaysılı, A., \& Aydın, Ş. (2015). A study on the educational, social and political expectations of the preservice 
teachers. Cumhuriyet International Journal of Education, 4(2), 1-14. https://doi.org/10.30703/cije.321365

Saban, A. (2003). Demographic characteristics and perceptions of prospective classroom teachers. Journal of Educational Research, 10, 91-101.

Sahlberg, P. (2011). The professional educator: Lessons from Finland. American Educator, 35(2), 34-38. https://eric.ed.gov/?id=EJ931215

Sarıbaş, S., \& Babadağ, G. (2015). Basic problems of basic education. Anadolu Ĕgitim Liderliği ve Öğretim Dergisi, Anatolian Journal of education and Leadership Instruction, 3(1), 18-34.

Schleicher, A. (2018). Valuing our teachers and raising their status: How communities can help, international summit on the teaching profession. Paris:OECD Publishing. https://doi.org/10.1787/9789264292697-en

Soydan, T. (2012). A research based on the views of managers and teachers about the effectiveness of the performance evaluation system in the field of education. Aegean Education Journal, 13(1), 1-25.

Symeonidis, V. (2015). The status of teachers and the teaching profession a study of education unions' perspectives. Retrieved from

https://download.eiie.org/Docs/WebDepot/The\%20Status\%20of\%20Teachers\%20and\%20the\%20Teaching\%20Pro fession.pdf

TEDMEM (2014). Teaching profession with teacher perspective. Ankara:TED Publising.

Tok, T. (1997). The level of the teaching profession meets the needs of teachers]. Eğitim Yönetimi, [Education Management, 3(2), 251-267.

Türkdoğan, S. C. (2014). The pre-service teachers' professional concerns according to the factors effective in choosing the teaching profession. (Unpublished Master Thesis), Pamukkale University Institute of Educational Science, Denizli, Turkey.

UNESCO (2017). Global education monitoring report. Paris: Unesco Paplising.

Ünsal, S. (2018). A Pareto Analysis of Status of Teaching Profession in Turkey. Sakarya University Journal of Education, 8(2), 11-130. https://doi.org/10.19126/suje.379040

Uygun, S. (2013). Problems of Turkish education system: Traditional and current. Ankara: Nobel Publising.

Yaman, E., Yaman, H., \& Eskicumal1, A. (2001). The situation of this profession into a female profession and a research on the faculty of education, Sakarya University Journal of Education, 2, 53-68.

\section{Copyrights}

Copyright for this article is retained by the author(s), with first publication rights granted to the journal.

This is an open-access article distributed under the terms and conditions of the Creative Commons Attribution license which permits unrestricted use, distribution, and reproduction in any medium, provided the original work is properly cited. 